\title{
FELVILÁGOSULT DOGMATIZMUS (ENLIGHTENED DOGMATISM)
}

Nyirkos Tamás, a középkori politikai filozófia (Bevezetés a világvégéhez. Joachim apát történeti misztikája), a francia ellenforradalmi gondolkodás (Az ötfejü sas. Teológia és politikai a francia ellenforradalomban), valamint a demokrácia és a többség zsarnoksága elméleteinek (The Tyranny of the Majority) kutatója Politikai teológiák címmel megjelent kötetében arra vállalkozik, hogy Carl Schmitt kifejezése, a „politikai teológia” nyomán a modernitás egyes ideológiáiról kimutassa azok teológiai jellegét: azt, hogy bár „híveik” ezeket mindenféle hitrendszertől független, racionálisan megalapozott konstrukcióknak tartják, valójában nemcsak teológiai gyökerüek, hanem menthetetlenül dogmatikusak is, és elfogadottságuk nem valamilyen észszerü belátáson, hanem a bennük való, olykor teljesen irracionális, magának kizárólagosságot követelő hiten nyugszik.

Nyirkos könyve bevallottan „elözetes vázlat egy sokkal átfogóbb tárgyaláshoz” (145.), és elsősorban ma már klasszikusnak számító filozófusok (Rousseau, Alexis de Tocqueville, Nyikolaj Bergyajev, Carl Schmitt), illetve kortárs gondolkodók írásainak kritikus vagy egyetértő ismertetését adja. Mindez azonban nem jelenti azt, hogy a szerző teljesen megbújik a tárgyalt szerzők müvei mögött, és ez nemcsak a sokszor polemikus megjegyzésekben nyilvánul meg, hanem néhány olyan mondatból is, amelyből kihámozható alapállása a témájához. Ezek egy, a modernség ideológiáival alapvetően kritikus szerzőt mutatnak, aki sorban megkérdőjelezi korunk olyan nagy „hittételeit”, mint a népszuverenitással és a demokráciával kapcsolatos idealizált elképzelések, vagy éppen a piac mindent szabályozó és mindent a legjobb irányba terelő működésének dogmája. Szó esik a kommunizmusról, amely magát a vallás meghaladásának állította be, miközben új vallást hozott létre, vagy éppen az emberi jogokról, melyeknek hívei ezeket örökkévalónak, egyetemesnek és „,minden vitán felül állónak” szeretnék tudni, holott a ,jogok” mint olyanok is csak néhány évszázada jelentek meg a nyugati gondolkodásban.

Miközben korunkat előszeretettel állítjuk be a felvilágosultság és a racionalitás korának, amelyet a tudomány haladása és a jólét elterjedése jellemez, szembeállítva a sötét, babonás középkorral, a középkorász szerző nemcsak a modernitás babonáira kíván rámutatni, hanem úgy véli, a modernség önnön mércéjével mérve is könnyűnek találtatik a középkorral szemben. „,[A] hit és az ész összhangját kereső középkori kereszténységgel szemben a modernség egyes ideológiái a racionalitás nyomait sem mutatják, vagyis sokkal inkább babonák, és sokkal több vakhitet követelnek, mint állítólag kevésbé felvilágosult elődeik" - olvashatjuk már a könyv bevezetésében (9.). 
A modernség talán legegyértelmübben negatív „vívmánya” a totalitarizmusok léte, amelyek a középkorban valóban elképzelhetetlenek lettek volna. Sokan keresték és keresik a választ arra, miként lehetséges, hogy felvilágosodottnak hitt korunkban előfordulhattak olyan szörnyüségek, mint Auschwitz és a Gulág (talán a legismertebb - és egyben legvitatottabb - válasz ebben a témában a Max Horkheimer és Theodor W. Adorno által jegyzett $A$ felvilágosodás dialektikája). Nyirkos Tamás nem veti fel explicit módon ezt a problémát - pedig ez is izgalmas elemzésekre adna lehetőséget -, mindenesetre az egy Rousseau kapcsán tett megjegyzése igencsak megfontolandó, és ez más fénytörésben állítja be a gyakran lesajnált középkort is. Rousseau ugyanis bírálja az állam és egyház elválasztásának középkori modelljét, miközben ez a modell „ezer évig mégiscsak fenntartott egy civilizációt, és sikeresen korlátozta mindkét hatalmat egymás által, lehetetlenné téve bármi olyasmit, amit a modern időkben totalitarizmusnak nevezünk" (94.). Ezzel szemben Rousseau-nak A társadalmi szerzódésben kifejtett nézetei az általános akarat mindenhatóságáról és a kötelező polgári vallásról a jakobinus diktatúra elméleti megalapozásául szolgáltak, a fasizmus-nácizmus, illetve a kommunizmus pedig ugyanúgy a korlátozhatatlan népfelségre hivatkozott a totális diktatúrák kiépítésekor, mint Robespierre.

Az első fejezetet leszámítva a sorban következő fejezetek egy-egy modern ideológiát vesznek górcső alá, és mutatják ki ezek teológiai gyökereit, előfeltevéseit, illetve igazolni igyekeznek azt a bevezetésben felvetett tételt, hogy ,a »politikai teológiák« pontosan a politikából kiszorított egyéb, mondjuk úgy, hagyományos hit-, gyakorlat- és intézményrendszerek ellenében, azok pótlására jöttek létre" (11.). Az első fejezet Carl Schmitt politikai teológiáról szóló nézeteit ismerteti, aki szerint ,a modern államelmélet minden jellemző fogalma szekularizált teológiai fogalom". A Politikai teológiák azonban bizonyos értelemben radikálisabb meghatározással él, amennyiben míg Schmitt egyértelmủen megkülönböztet vallási és világi teológiát, addig e kötet alapvetése szerint még csak ilyen különbség sem tehető, hanem a világi teológiák is vallási teológiák (habár a „vallás” szó használatát annak problematikussága miatt igyekszik kerülni), így „,szekularizált" teológiai fogalmak helyett „rejtett” teológiai fogalmakról beszél.

A schmitti elgondolásokból kiindulva a kötet párba állítja a teológiai, illetve a világi(nak gondolt) fogalmakat: ebben az összeállításban a szuverénnek Isten, a polgári törvénynek a természeti törvény, a kivételes állapotnak a csoda, a konzervativizmusnak a teizmus, a liberalizmusnak a deizmus, a demokráciának a panteizmus, a marxizmusnak és az anarchizmusnak pedig az ateizmus felel meg. A második fejezet aztán a szuverenitás fogalmát veszi górcső alá, fogalomtörténetileg kimutatva, hogy a „szuverén” jelző előbb Istenre, majd a föpapra, s csak aztán vonatkozott a világi vezetőkre (32.). A következő lépést Rousseau jelentette, aki a király helyett a szuverenitást a nép kezébe adta. Ez a szuverenitás vagy főhatalom A társadalmi szerzödésben számos isteni attribútummal rendelkezik, 
így a népszuverenitás vagy más néven az általános akarat oszthatatlan, szent és sérthetetlen, tévedhetetlen és halhatatlan (38.).

Ez a nép szentségébe és mindenhatóságába vetett hit minden demokratikus rendszer lényege, miközben racionális alapja nincs, tehát vakon kell hinni benne - állítja a kötet. Ugyanilyen vakhit szolgál alapul a többség mindenhatósága és tévedhetetlensége harmadik fejezetben elemzett dogmájának, amely a demokráciák egyik sajátos babonája. Tocqueville ezt a dogmát a „többség zsarnoksága” címszava alatt tárgyalja részletesen, és ahogy a Politikai teológiák harmadik fejezete meggyőzően kimutatja, maga is nagyon sok teológiai előfeltevéssel él, sőt a történelem haladásában kifejezetten a Gondviselés müvét látja. Ahogy Nyirkos Tamás jól mutat rá, a többség tévedhetetlensége olyannyira rögzült elképzelés, hogy ha a többség valamit igazként fogad el, míg mi hamisnak hisszük, először nem az jut eszünkbe, hogy a többség tévedhet, hanem hogy biztos mi magunk tudjuk rosszul. Hasonlóan, ha a többség egy választás alkalmából úgymond „rosszul” dönt, nem az hangzik el, hogy a nép önmagától ítélt tévesen, hanem hogy valakik félrevezették őket. A kötet Tocqueville mellett a demokráciakritika nálunk olyan kevésbé ismert szerzőinek felfogását is ismerteti, mint Gaetano Moscáé, Vilfredo Paretóé vagy Erik Ritter von Kuehnelt-Leddihné.

A negyedik fejezetben a kommunizmus és a nácizmus teológiai vonatkozásai, az ötödikben a polgári vallás rousseau-i fogalma, illetve a sajátos, ószövetségi messianisztikus politikai küldetéstudattal terhelt amerikai vallásosság kerül terítékre, hogy aztán a hatodik fejezetben ,a gazdaság teológiáiról” legyen szó a kötet talán legizgalmasabb fejezetében. Itt a piaci fundamentalizmus dogmái lepleződnek le, a piacé, amelynek ,láthatatlan keze” állami beavatkozás nélkül is mindig a megfelelő irányba tereli a gazdaságot, amely megmutatja az erről mit sem sejtö embereknek, mire van szükségük, s amelynek olyan isteni mindenhatóságot és tévedhetetlenséget tulajdonítanak, hogy a közgazdasági vitákban rendszeresen elhangzó érvvé - a „piac ezt akarja” - vált. Persze, ahogy a kötet a piac ideológiáját leleplezően rámutat, ,aki a piac igényeiről szónokol, a legtöbbször csak arra akar rávenni minket, hogy azt tegyük, amit ő akar" (110.). Szó esik még a piac melletti másik nagy istenségről, a pénzről, majd a közgazdaságtan „,papjairól”, az iskolateremtő közgazdászokról, hogy aztán az utolsó fejezetben a fogyasztási ideológiák ellentétének, a mélyökológiának az irracionalitásai kerüljenek kitárgyalásra.

A Politikai teológia vázlatossága ellenére is átfogó képet ad a modern politikai gondolkodás teológiai jellegéről, számos izgalmasnak tünő könyv felé tágítva ki az olvasó szemhatárát. Ha a filozófia feladatának a mindenben való kételkedést, mindennek megkérdőjelezését tekintjük, akkor ez a kötet kiválóan teljesíti ezt a célt, alapvetőnek hitt igazságokról rántva le a leplet és mutatva be, hogy korántsem annyira magától értetődők, mint azt gondolni vagyunk hajlamosak. És ez különösen fontos akkor, ha igaza van abban a borús diagnózisban, amit modern 
korunkról ad: „A racionális érvelés eltűnése a kortárs vitákból természetesen általános jelenség [...]. Egyre dogmatikusabb világban élünk, ahol a kötelező tanokat már óvodától kezdve vésik be a gyermekek elméjébe [...]. Az eretnekeket persze - ahogy Tocqueville is megjósolta - nem vetik máglyára, viszont ma már közel sem számít olyan botrányosnak kizárásuk bizonyos fórumokról és intézményekből, mint a klasszikus liberalizmus korszakában" (132.).

(Nyirkos Tamás: Politikai teológiák. A demokráciától az ökológiáig. [PANTA Pázmány Nemzetközi Tanulmányok], Budapest: Typotex Kiadó, 2018, 160 o.)

Kiss Csaba

PhD, filozófus 